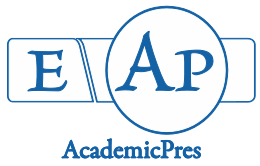

Banu F et al. (2020)

Notulae Scientia Biologicae 12(2):251-257

DOI: $10.15835 / \mathrm{nsb} 12210661$

Research Article

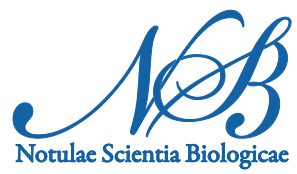

\title{
Molecular variation and phylogenetic status of ponyfish (Perciformes: Leiognathidae) in Karaikal, South India
}

\author{
Firudoz BANU, Vellaichamy RAMANADEVI, Gunasekar SHALINI, \\ Muthusamy THANGARAJ*
}

Annamalai University, Faculty of Marine Sciences, Centre for Advanced Study in Marine Biology, Parangipettai, Tamil Nadu 608 502, India; coralholder@yahoo.com (*correspondingauthor)

\begin{abstract}
The family Leiognathidae, commonly known as ponyfish and they are mainly classified by mouth morphology. In this study, genetic variation and phylogenetic relationships among nine genera and 13 species of Leiognathidae, inferred from Cytochrome Oxydase I gene. The Neighbour Joining tree showed the paraphyly of the studied species form genus Secutor and monophyly status all the other eight genera. Leiognathus equulus is occupying a basal branch of the family NJ tree. The highest genetic distance (0.349) showed between Eubleekeria and Nuchequula. The lowest genetic distance (0.007) showed between the genus Nuchequula and Leiognathus. Among the nine genera, very less nucleotide diversity $(\pi=0.1100)$ was in Secutor and higher value ( $\pi=0.7558$ ) was recorded in Leiognathus. The Tajima's test statistic $(D)$ value was positive, so, the entire genus is in balancing selection.
\end{abstract}

Keywords: COI; genetic variation; Leiognathidae; NJ tree; nucleotide diversity

\section{Introduction}

Leiognathids (family: Leiognathidae) are food fishes commonly known as slip mouths or ponyfishes. They are represented by about 30 species and distributed over most of the Indo-Pacific area, ranging from South Africa in the west to Tahiti in the east, and from Australia in the south to Japan and the Red Sea in the north (Froese and Pauly, 2017). They characterized by having a highly protractible mouth and a circumesophageal light organ harboured various luminescent bacterium (Kaeding et al., 2007). The family comprises nine genera, namely Gazza, Leiognathus, Secutor, Photopectoralis, Nuchequula, Eubleekeria, Equulites, Aurigequla and Karalla (Chakrabarty et al., 2008; Eschmeyer, 2010; Abraham et al., 2011).

Leiognathids fishes are difficult to diagnose and identify based on external characteristics like shape, size and colours of body parts because they are morphologically similar among genera, and may form species complex (Sparks et al., 2005). Hebert et al. (2003) introduced the concept of DNA based barcoding system for species identification in the animal kingdom. This DNA barcode system has been successfully used in many fishes worldwide (Costa and Carvalho, 2007). It is a helpful tool to resolve some uncertainties of identification and also enhance the taxonomic revision (Chakrabarty and Sparks, 2008). Family-level phylogenetic analysis 
has provided a better understanding of the relationship of Leiognathids at the generic and species levels (Ikejima et al., 2004; Sparks and Dunlap, 2004). Such phylogenetic analysis of Indian Leiognathid fishes is lacking. Therefore, here, the phylogenetic assessment and genetic variation in four ponyfish species on Karaikal coast using COI gene sequences was studied and discussed.

\section{Materials and Methods}

\section{Sample collection}

Leiognathus equulus, Nuchequula blochii, Karalla dussumieri and Photopectoralis bindus were collected from the Karaikal landing center $\left(10^{\circ} 55^{\prime} 31.58^{\prime \prime} \mathrm{N}\right.$ and $\left.79^{\circ} 50^{\prime} 16.82^{\prime \prime} \mathrm{E}\right)$, in the Southeast coast of India. Ten individuals were taken from each fish species and the tissue samples (caudal fin) were dissected and stored in $95 \%$ ethanol for DNA isolation.

\section{DNA isolation and PCR}

DNA was isolated by standard Proteinase-K/Phenol- Chloroform- Ethanol method (Sambrook et al., 1989). The quality of the DNA was checked by measuring the ratio of absorbance at $260 \mathrm{~nm}$ and $280 \mathrm{~nm}$


amplified in a $50 \mu \mathrm{l}$ volume PCR mix with $5 \mu \mathrm{l}$ of $10 \mathrm{X}$ Taq polymerase $\mathrm{MgCl}_{2}(25 \mathrm{mM})$ buffer, $1 \mu \mathrm{l}$ of each $\mathrm{dNTP}(0.05 \mathrm{mM}), 1 \mu \mathrm{l}$ of each primer $(0.01 \mathrm{mM}), 0.6 \mathrm{U}$ of Taq polymerase, $2 \mu \mathrm{l}$ of genomic DNA and $36 \mu \mathrm{l}$ of double distilled water. The universal primer, FishF1-5'TCAACCAACCACAAAGACATTGGCAC3' and FishR1- 5'TAGACTTCTGGGTGGCCAAAGAATCA3' (Ward et al., 2005) was used for the amplification of the COI gene. The thermal regime consisted in an initial step of $2 \mathrm{~min}$ at $95^{\circ} \mathrm{C}$ followed by 35 cycles of $30 \mathrm{sec}$ at $94^{\circ} \mathrm{C}, 30 \mathrm{sec}$ at $54^{\circ} \mathrm{C}$ and $60 \mathrm{sec}$ at $72^{\circ} \mathrm{C}$ followed by final extension of $10 \mathrm{~min}$ at $72^{\circ} \mathrm{C}$. The PCR products were checked using 1.5\% agarose gel and the most representative bands were selected for sequencing. The cleaned-up PCR product was sequenced by a commercial sequencing facility (Macrogen, Korea).

\section{Sequence analysis}

The partial COI gene sequences of eight individuals were edited using MEGA 5.0 (Kumar et al., 2011) and aligned with Clustal W 1.6. The haplotype definitions have been submitted to the NCBI GenBank through Bank its portal. To support the hereby studied eight COI sequences of four genus, another 18 sequences of five genus were retrieved from NCBI GenBank. The nucleotide diversity $(\pi)$ (Lynch and Crease, 1990) and Tajima's D (Tajima, 1989) was calculated in Dnasp 4.0 (Rozas et al., 2003). Genetic relationships among individuals were constructed based on the neighbor-joining (NJ) method (Saitou and Nei, 1987).

\section{Results and Discussion}

\section{Species confirmation and genetic distance}

All the six sequences get assigned the accession number as MT000154, MT000163, MT000164, MT000165, MT000169, MT000310, MT000311, MT000312. During BLAST, all the sequences showed 99\% identity of more than $90 \%$ query coverage with previously published COI gene sequences of Leiognathus equulus, Nuchequula blochii, Karalla dussumieri and Photopectoralis bindus in the NCBI's nucleotide database and confirmed the species (Figure 1).

Among the nine genus the $\mathrm{A}+\mathrm{T}$ content of the $\mathrm{COI}$ gene was ranged from 51.76 to $53.99 \%$ the $\mathrm{G}+\mathrm{C}$ content was from 46.01 to $48.26 \%$ (Figure 2). Genetic distance was measured by K2P parameter within and 
between genus of Leiognathidae and the result is shown in Table 1. The highest genetic distance (0.349) showed between Eubleekeria and Nuchequula. The lowest genetic distance (0.007) showed between the genus Nuchequula and Leiognathus.

\section{Tajima's test for neutrality}

Tajima's test was performed using all the COI gene sequences from nine genus of Leiognathidae. Among the nine genera, very less nucleotide diversity $(\pi=0.1100)$ was in Secutor and higher value $(\pi=0.7558)$ was recorded in Leiognathus. The Tajima's test statistic $(D)$ value was showed positive, so this entire genus is in balancing selection (Table 2).

\begin{tabular}{|c|c|c|c|c|c|c|c|c|}
\hline Genus & Leiognathus & Karalla & Nuchequula & Photopectoralis & Gazza & Aurigequula & Equulites & Eubleekeria \\
\hline Karalla & 0.289 & & & & & & & \\
\hline Nuchequula & 0.007 & 0.283 & & & & & & \\
\hline Photopectoralis & 0.299 & 0.227 & 0.294 & & & & & \\
\hline Gazza & 0.267 & 0.284 & 0.266 & 0.327 & & & & \\
\hline Aurigequula & 0.131 & 0.310 & 0.133 & 0.344 & 0.252 & & & \\
\hline Equulites & 0.281 & 0.259 & 0.278 & 0.217 & 0.290 & 0.281 & & \\
\hline Eubleekeria & 0.340 & 0.299 & 0.349 & 0.298 & 0.280 & 0.327 & 0.333 & \\
\hline Secutor & 0.309 & 0.294 & 0.307 & 0.291 & 0.193 & 0.275 & 0.288 & 0.313 \\
\hline
\end{tabular}

Table 1. K2P genetic distance between genus of the Leiognathidae family

Table 2. Tajima's Neutrality Test for COI gene in Leiognathidae family

\begin{tabular}{|c|c|c|c|c|c|}
\hline Genus & $M$ & $S$ & $P S$ & $\pi$ & $D$ \\
\hline Leiognathus & 2 & 593 & 0.94426 & 0.7558 & 5.0587 \\
\hline Karalla & 4 & 614 & 0.9839 & 0.7518 & 4.2130 \\
\hline Nuchequula & 2 & 561 & 0.9130 & 0.7165 & 4.4693 \\
\hline Photopectoralis & 2 & 460 & 0.7313 & 0.4880 & 2.7431 \\
\hline Gazza & 4 & 464 & 0.7353 & 0.4899 & 2.3275 \\
\hline Aurigequula & 2 & 600 & 0.9404 & 0.7439 & 4.7054 \\
\hline Equulites & 2 & 483 & 0.7618 & 0.5320 & 1.2014 \\
\hline Eubleekeria & 2 & 471 & 0.7239 & 0.5163 & 1.7642 \\
\hline Secutor & 4 & 107 & 0.1651 & 0.1100 & 2.3256 \\
\hline
\end{tabular}

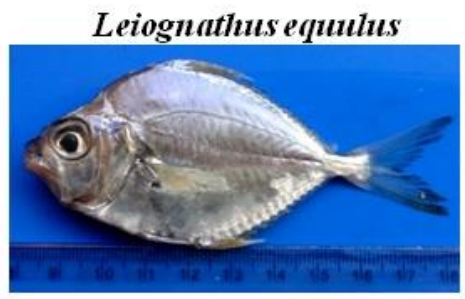

Karalla dussumieri



Nuchequulablochii

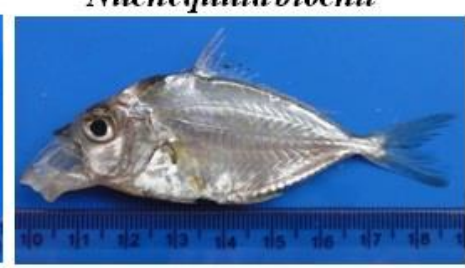

Photopectoralis bindus



Figure 1. The Leiognathid fishes collected from Karaikal 


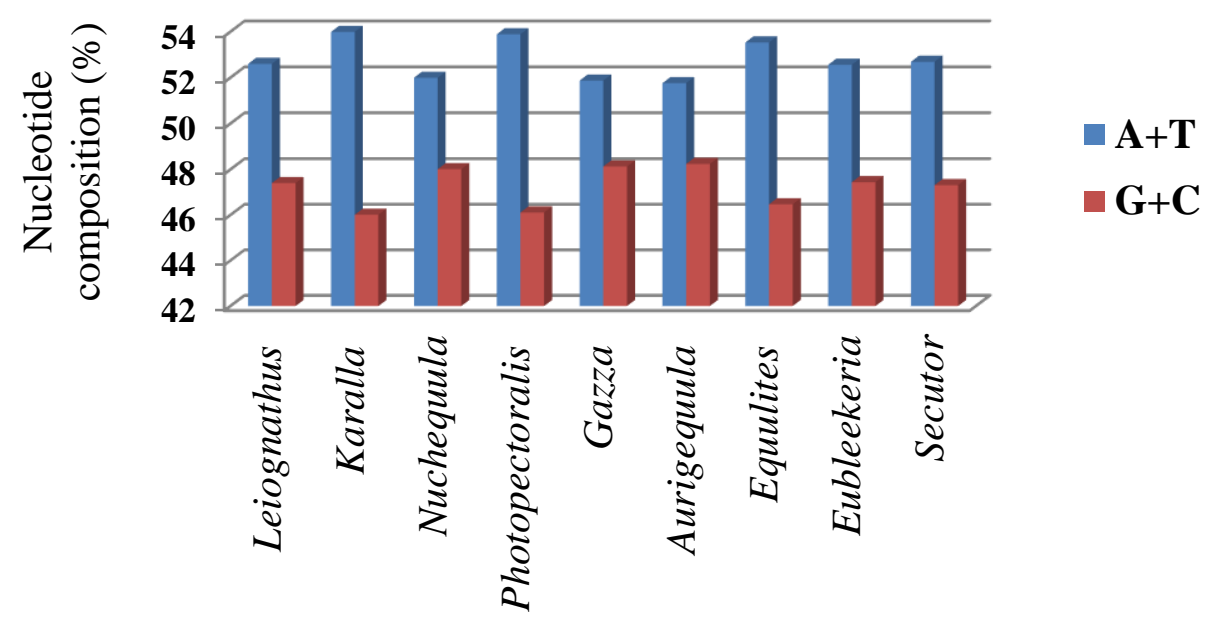

Figure 2. Nucleotide composition of COI gene in different genus of Leiognathidae

\section{Phylogenetic tree}

Figure 3 shows the phylogenetic tree constructed by the partial COI gene sequences of Leiognathidae species using neighbour-joining algorithm with distance scale. This tree shows three major clades with high bootstrap values. The first clad includes Leiognathus, Nuchequula, Aurigequula, Gazza and Eubleekeria. The second clade contains Karalla, Potopectoralis and Equulites. The third minor clad only occupied by Secutor recoinus. Interestingly another Secutor species, Secutor insidiator occupies the first major clade. All the nodes in the tree showed above $50 \%$ bootstrap values and indicate that reliable phylogenetic relationship pattern. Similar results were obtained by Ikejima et al. (2004), Sparks and Dunlap (2004) and Sparks et al. (2005) using a combination of different genetic markers. The clade containing Photopectoralis was more closely related to Equulites and Karalla in the subset tree. Earlier report (Seah et al., 2008) showed P. bindus and L. jonesi formed the base of the Gazza, Secutor and Photoplagios clades.

In this study the level of intra-species variation was low which may be due to the low number of haplotypes identified in the sample with limited numbers collected for this study. Similarly, Lakra et al. (2011) reported very low intra-specific genetic divergence for scombroid fishes. Peris et al. (2009) also recorded very low within species genetic distance for Indian carangid fishes. Ward et al. (2005) identified that, in COI of fishes the GC content was $42.2-47.1 \%$, which reflects in this study. The mean GC content was 46.01 to $48.26 \%$ among the nine genera. The mean nucleotide diversity $(\mathrm{Pi})$ among the 13 species was estimated at 0.5671. Earlier studies in Indian marine fishes it was estimated at 0.2029 (Lakra et al., 2011).

The absolute clustering of conspecifics in the present study indicates the diagnostic ability of COI to correctly identify species. Carangoids are hypothesized to be close relatives of pony fishes (Sparks et al., 2005) were used as out group in the present study. Here in neighbour-joining reconstruction, the monophyly of Leiognathidae was strongly supported by a bootstrap value of $100 \%$. Earlier, within Leiognathidae family, six clades of Nuchequula, Photoplagios, Photopectoralis, Gazza and Secutor with bootstrap support of $94 \%,<50 \%$, $83 \%, 100 \%$ and $81 \%$ by Seah et al. (2008). Sparks et al. (2005) suggested that Aurigequula fasciata and Leiognathus equulus each formed independent species complex. Both do not appear to be internally or externally sexually dimorphic with regard to the light organ system. Phylogenetic analysis in this study indicated that Aurigequula fasciata, which also do not exhibit sexual dimorphism of the light organ, formed a sister group to Leiognathus equulus. Secutor insidiator and Secutor ruconius have a small sized body and are probably sister taxa. But molecular data placed these two species in different clade. Sparks et al. (2005) showed that Secutor ruconius was a sister taxon to $S$. hanedai and $S$. megalolepis. 


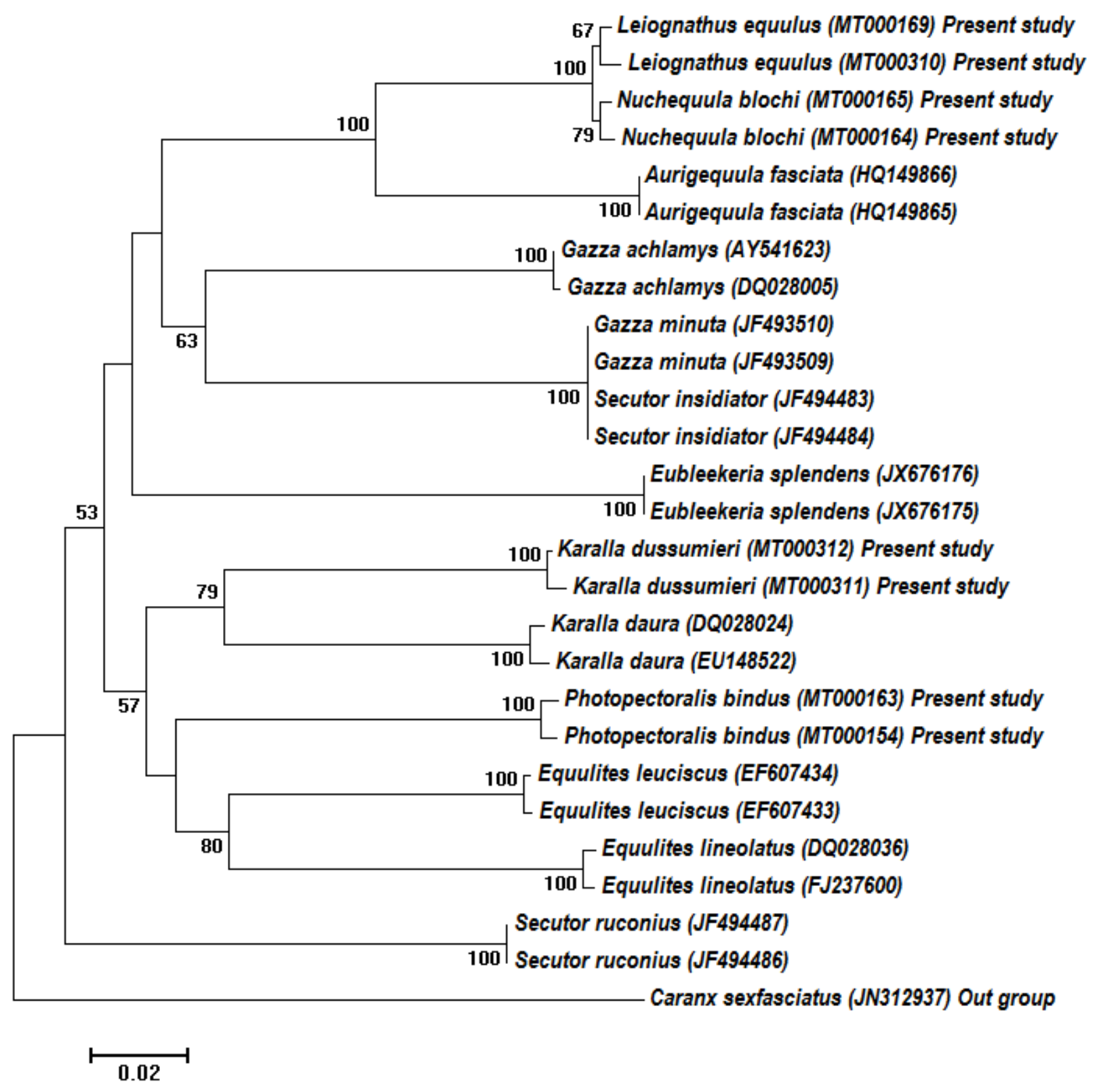

Figure 3. Neighbour-joining phylogenetic tree using COI gene sequences

The molecular phylogenetic positions of the fishes were in congruence with morphological delineation. These results, and those from previous studies, suggested that a more robust morphological criterion, coupled with relevant molecular data should be employed to resolve taxonomic uncertainties among this group of fishes.

Acknowledgements

We thank the Dean and Director CAS in Marine Biology and The Authorities of Annamalai University for providing facility and encouragement. 


\section{Conflict of Interests}

The authors declare that there are no conflicts of interest related to this article.

\section{References}

Abraham KJ, Joshi KK, Murty VSR (2011). Taxonomy of the fishes of the family Leiognathidae (Pisces, Teleostei) from the West coast of India. Zootaxa 2886:1-18. https://doi.org/10.11646/zootaxa.2886.1.1

Chakrabarty P, Sparks JS (2008). Diagnoses for Leiognathus Lacepede 1802, Equula Cuvier 1815, Equulites Fowler 1904, Eubleekeria Fowler 1904, and a new ponyfish genus (Teleostei: Leiognthidae). American Museum Novitates 3623:1-11.https://doi.org/10.1206/618.1

Chakrabarty P, Amarasinghe T, Sparks JS (2008). Redescription of ponyfishes (Teleostei: Leiognathidae) of Srilanka and the status of Aurigequula Fowler 1918. Ceylon Journal of Science (Biological Sciences) 37(2):143-161. https://doi.org/10.4038/cjsbs.v37i2.502

Costa FO, Carvalho GR (2007). The barcode of life initiative: synopsis and prospective societal impacts of DNA barcoding of fish. Genomics Society and Policy 3:29-40. https://doi.org/10.1186/1746-5354-3-2-29

Eschmeyer WN (2010). Catalog of fishes. Electronic version (Updated 25th October 2010). http://research.calacademy.org/research/ichthyology/catalog/fishcatsearch.html

Froese R, Pauly D (2017). Fish Base. World Wide Web Electronic Publication. www.fishbase.org

Hebert PDN, Cywinska A, Ball SL, Waard JRD (2003). Biological identifications through DNA barcodes. Proceedings of the Royal Society of London. Series B: Biological Sciences 270:313-321. https://doi.org/10.1098/rspb.2002.2218

Ikejima K, Ishiguro NB, Wada M, Tsukamoto K, Nishida M (2004). Molecular phylogeny and possible scenario of ponyfish (Perciformes: Leiognathidae) evolution. Molecular Phylogenetic and Evolution 30:904-909. https://doi.org/10.1016/j.ympev.2003.10.006

Kaeding AJ, Ast JC, Pearce MM, Urbanczyk H, Kimura S, Endo H, ... Dunlap PV (2007). Phylogenetic diversity and cosymbiosis in the bioluminescent symbioses of Photobacterium mandapamensis. Applied and Environmental Microbiology 73:3173-3182. https://doi.org/10.1128/aem.02212-06

Lakra WS, Verma MS, Goswami M, Lal KK, Mohindra V, Punia P, ... Hebert P (2011). DNA barcoding Indian marine fishes. Molecular Ecology Resources 11:60-71. https://doi.org/10.1111/j.1755-0998.2010.02894.x

Lynch M, Crease TJ (1990). The analysis of population survey data on DNA sequence variation. Molecular Biology and Evolution 7(4):377-394. https://doi.org/10.1093/oxfordjournals.molbev.a040607

Peris M, Chandra Sekhar Reddy A, Rao LM, Khedkar GD, Ravinder K, Nasruddin K (2009). COI (Cytochrome oxidaseI) sequence-based studies of Carangid fishes from Kakinada coast, India. Molecular Biology Reports 36:17331740. https://doi.org/10.1007/s11033-008-9375-4

Rozas J, Sanchez-DelBarrio JC, Messeguer X, Rozas R (2003). Dna SP, DNA polymorphism analyses by the coalescent and other methods. Bioinformatics 19(18):2496-2497. https://doi.org/10.1093/bioinformatics/btg359

Saitou N, Nei M (1987). The neighbor-joining method: a new method for reconstructing phylogenetic trees. Molecular Biology and Evolution 4(4):406-425. https://doi.org/10.1093/oxfordjournals.molbev.a040454

Sambrook J, Fritsch EF, Maniatis T (1989). Molecular cloning: a laboratory manual, second ed. Cold Spring Harbor Laboratory Press, New York, Cold Springs Harbor, pp 1626.

Seah YG, Ghaffar MA, Usup G (2008). Phylogeny of ponyfishes from coastal waters of the South China Sea. Journal of Applied Biological Sciences 2(3):125-133.

Sparks JS, Dunlap PV (2004). A clade of non-sexually dimorphic ponyfishes (Teleostei: Perciformes: Leiognathidae): phylogeny, taxonomy and description of a new species. American Museum Novitates 3459:1-21. https://doi.org/10.1206/0003-0082(2004)459<0001:acondp>2.0.co;2

Sparks JS, Dunlap PV, Smith WL (2005). Evolution and diversification of a sexually dimorphic luminescent system in ponyfishes (Teleostei: Leiognathidae), including diagnoses including diagnoses for two new genera. Cladistics 21:305-327.https://doi.org/10.1111/j.1096-0031.2005.00067.x 
Tajima F (1989). Statistical methods to test for nucleotide mutation hypothesis by DNA polymorphism. Genetics 123:585-595. https://pubmed.ncbi.nlm.nih.gov/2513255/

Tamura K, Peterson D, Peterson N, Stecher G, Nei M, Kumar S (2011). MEGA5: Molecular evolutionary genetics analysis using maximum likelihood, evolutionary distance, and maximum parsimony methods. Molecular Biology and Evolution 28:2731-2739. https://doi.org/10.1093/molbev/msr121

Ward RD, Zemlac TC, Innes BH, Last PR, Hebert PDN (2005). DNA barcoding Australia's fish species. Philosophical Transactions of the Royal Society B: Biological Sciences 360(1462):1847-1857. https://doi.org/10.1098/rstb.2005.1716

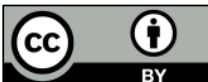

The journal offers free, immediate, and unrestricted access to peer-reviewed research and scholarly work. Users are allowed to read, download, copy, distribute, print, search, or link to the full texts of the articles, or use them for any other lawful purpose, without asking prior permission from the publisher or the author.

License - Articles published in Notulae Scientia Biologicae are Open-Access, distributed under the terms and conditions of the Creative Commons Attribution (CC BY 4.0) License.

(c) Articles by the authors; SHST, Cluj-Napoca, Romania. The journal allows the author(s) to hold the copyright/to retain publishing rights without restriction. 